\title{
Biosaline Agriculture
}

and Salinity Tolerance in Plants

Edited by Münir Öztürk, Yoav Waisel, M. Ajmal Khan and Güven Görk 


\title{
Vegetative bioremediation of sodic and saline-sodic soils for productivity enhancement and environment conservation
}

\author{
Manzoor Qadir ${ }^{1}$, Jim D. Oster ${ }^{2}$, Sven Schubert ${ }^{3}$ and Ghulam Murtaza ${ }^{4}$ \\ ${ }^{1}$ International Centerfor Agricultural Research in the Dry Areas, PO Box 5466,Aleppo. \\ Syria \\ 2 Department of Environmental Sciences, University of California,USA \\ ${ }^{3}$ Institute of Plant Nutrition, Justus Liebig University, Giessen, Germany \\ ${ }^{4}$ Institute of Soil and Environmental Sciences, University of Agriculture. Faisalobud, \\ Pakistan
}

\section{Introduction}

Salt-affected soils occupy nearly $20 \%$ of irrigated area worldwide [1]. As a major category ofsalt-affected soils, sodic and saline-sodic soils are characterized by the occurrence of sodium $\left(\mathrm{Na}^{+}\right)$at levels that result in poor physical properties and fertility problems, thereby threatening agricultural productivity in many arid and semi-arid regions. Amelioration of these soils is driven by providing a soluble source of calcium $\left(\mathrm{Ca}^{2+}\right)$ to replace excess $\mathrm{Na}^{+}$on the cation exchange complex [2]. The displaced $\mathrm{Na}^{+}$is either leached from the root zone by excess irrigation, aprocess that requires soil permeability and provision of a natural or artificial drainage system, or is taken up by crops.

Many sodic and saline-sodic soils contain inherent or precipitated sources of $\mathrm{Ca}^{2+}$, i.e., calcite $\left(\mathrm{CaCO}_{3}\right)$ at varying depths. Due to its negligible solubility $(0.14$ $\mathrm{mmol} \mathrm{L}^{-1}$ ), natural dissolution of calcite does not provide sufficient $\mathrm{Ca}^{2+}$ to ameliorate these soils. Consequently, amelioration of these soils has been dominated by the application of chemical amendments [3]. Some amendments supply soluble sources of $\mathrm{Ca}^{2+}$ to the soil solution, which then replace excess $\mathrm{Na}+$ on the exchange complex, while others assist in increasing the dissolution rate of calcite. There have been constraints with chemical amelioration in several developing countries during the last two decades because of 1) low-quality of amendments containing a large fraction of impurities, 2) restricted availability of amendments when needed for amelioration, and/or 3) increased costs of amendments due to competing demands by industry and reductions in government subsidies for their agricultural use. Owing to oveniding importanceof the lastfactor, chemical amelioration bas become prohibitivelyexpensive for resource-poorfanners. However, there is growing evidence from researchers and farmers indicatingthat these soils can be brought back to a highly productive state 
using a plant-assisted amelioration approach - vegetative bioremediation- that does not rely on chemical amendments [4-6]. Synonymous terms for vegetative bioremediation include phytomelioration, phytoremediation, and biological reclamation.

Typical plant-assisted amelioration strategies for contaminated soils, such as those containing elevated levels of heavy metals and metalloids, work through cultivation of specific plant species capable of hyper-accumulation of target ionic species in their shoots, thereby removing them from the soil [7]. In contrast, vegetativebioremediation of sodic and saline-scdic soils is achieved by the ability of plant roots to increase the dissolution rate of calcite, thereby resulting in enhanced levels of $\mathrm{Ca}^{2+}$ in soil solution. The salinity-scdicity combination present in the soil solution during vegetative bioremediation maintains adequate soil structure and aggregate stability that enhance the amelioration process [8]. This chapter highlights the role of cropping for vegetativebioremediationof calcareous sudic and saline-sodicsoils and its evaluation against other amelioration approaches. This information will assist researchers and farmadvisors in choosing appropriate crops as well as crop, soil and irrigation management practices to achieve maximum benefit during the amelioration process.

Vegetative bioremediation of sodic and saline-sodic soils

Vegetative bioremediation of calcareous sodic and saline-sodic soils is a promising option that increases the dissolution rate of calcite through the processes at the soil-root interface resulting in enhanced levels of $\mathrm{Ca}^{2+}$ in soil solution. Vegetative bioremediation $\left(V_{\mathrm{Bio}}\right)$ is a function of the following factors:

$$
V_{\mathrm{Bio}}=\sum R_{\mathrm{PCO} 2}+R_{\mathrm{H}^{+}}+R_{\mathrm{Phy}}+S_{\mathrm{Na}^{+}}
$$

where $R_{\mathrm{PCO}_{2}}$ refers to increased partial pressure of $\mathrm{CO}_{2}$ within the root zone. $R_{\mathrm{H}+}$ is enhanced proton $\left(\mathrm{H}^{+}\right)$release in the root zone in case of certain $\mathrm{N}_{2}$-fixing crops, $R_{\text {Phy }}$ deals with physical effects of roots in improving soil aggregationand hydraulic properties of the root zone, and $S_{\mathrm{Na}^{+}}$consists of $\mathrm{Na}^{+}$content of shoot which is removed through harvest of aerial plant portion. The collectiveeffects of these factors ultimately lead to soil amelioration, provided leaching and drainage are adequate [Fig. 1).

\section{Comparative efficiency of vegetative bioremediation}

The evaluation of vegetative bioremediation and chemical approaches in various countries reveals comparable performance of both in terms of sodic soil amelioration. Results of a field experiment conducted on a barren, calcareous, alkali soil $\left(\mathrm{pH}_{12}=\right.$ $\left.10.6, \mathrm{EC}_{1: 2}=2.7 \mathrm{dS} \mathrm{m}^{-1}, \mathrm{ESP}=94\right)$ indicated that the ameliorationefficiency of two grasses, Para grass (Brachiaria mutica (Forssk.) Stapf) and Kamal grass (Leptochloa fusca (L.) Kunth), was comparable with soil application of gypsum at $12.5 \mathrm{Mg}$ $\mathrm{ha}^{-1}$ [9]. The yield of first rice (Oryza sativa L.) crop in the gypsum treatment averaged $3.7 \mathrm{Mg} \mathrm{ha}^{-1}$ as compared to 3.8 and $4.1 \mathrm{Mg} \mathrm{ha}^{-1}$ from the treatments cropped for 1 year with Para and Kamal grasses, respectively. The corresponding 


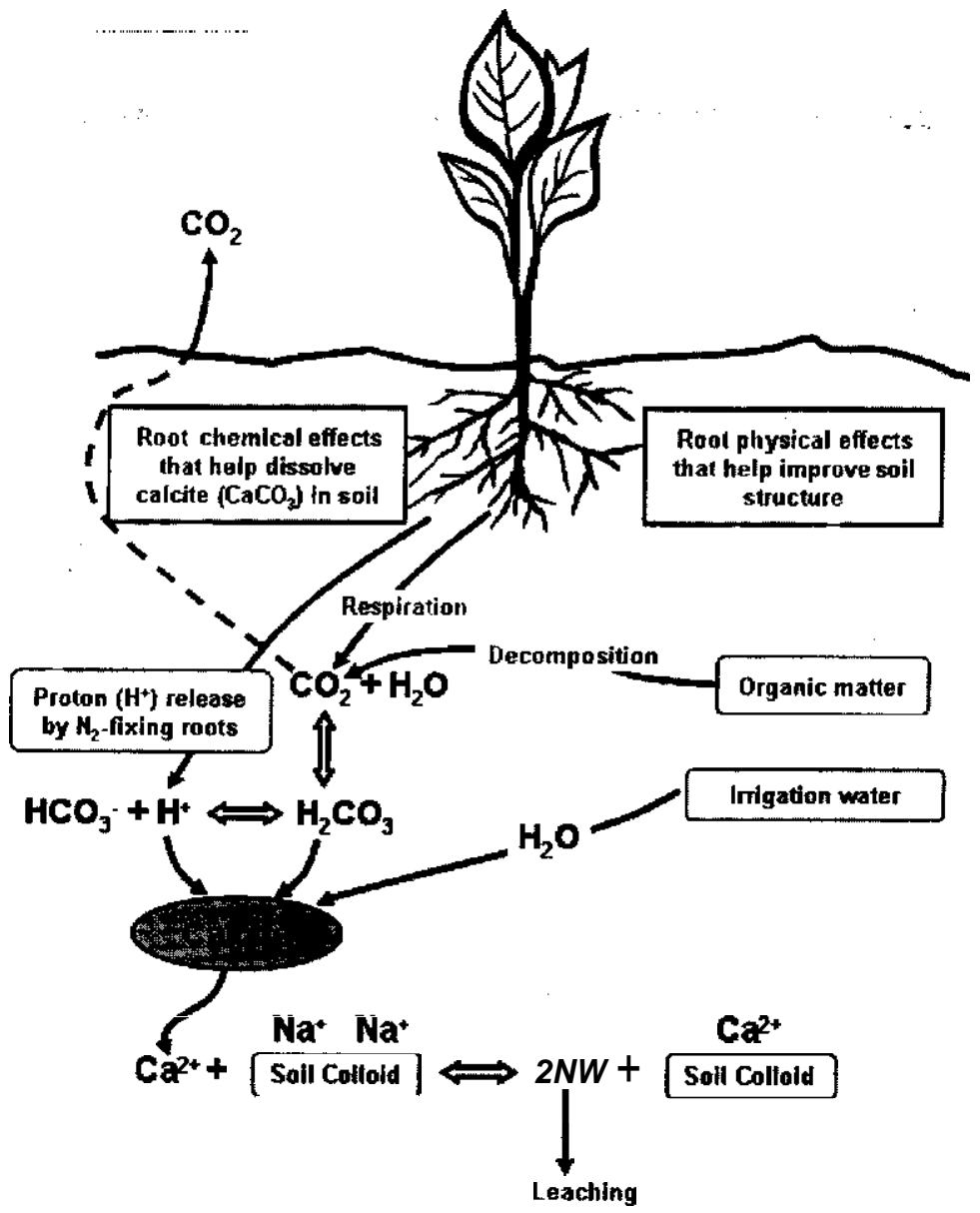

Figure 1. A conceptual model for the chemical reactions involved in calcite $\left(\mathrm{CaCO}_{3}\right)$ dissolution and amelioration of calcareous sodic and saline-sodicsoils during vegetative bioremediation

rice yields after 2 years of grass cropping were 5.3 and $6.1 \mathrm{Mg} \mathrm{ha}^{-1}$. In another field experiment [10], amelioration efficiency of Kallar grass was evaluated during different periods of root decay by leaching a calcareous, silty clay loam, saline-sodic soil $\left(\mathrm{pH},=8.3-9.3, \mathrm{EC},=16.8-37.5 \mathrm{dS} \mathrm{m}^{-1}, \mathrm{SAR}=32.5-108.9\right) 3,6,9$, and 12 days after each harvest during 2 years of grass cultivation. Each plot was kept flooded for 3 days during leaching. The amelioration efficiency of Kallar grass was greater in the plots leached 6 days after harvesting, and it was comparable with gypsum-treated soil.

In a field study [11], cropping of seshania (Sesbania bispinosa (Linn.) W.E Wight), Kallar grass, and sordan (Sorghum xdrummondii (Steud.) Millsp. \&Chase) was compared against gypsum application $\left(13 \mathrm{Mg} \mathrm{ha}^{-1}\right)$ on a calcareous, sandy clay 
loam, saline-sodic soil ( $\left.\mathrm{pH},=8.2-8.6, \mathrm{EC},=7.4-9.0 \mathrm{dS} \mathrm{m}^{-1}, \mathrm{SAR}=55.6-73.0\right)$. The plant species were grown for two seasons ( 15 months) with average forage yields in the order: sesbania(40.8 $\left.\mathrm{Mg} \mathrm{h} \mathrm{a}^{1}\right)>$ Kallar grass $\left(29.3 \mathrm{Mg} \mathrm{ha}^{-1}\right)>\operatorname{sordan}(24.7$ $\mathrm{Mg} \mathrm{ha} \mathbf{~}^{\mathbf{1}}$ ). After two cropping seasons, the treatment efficiency for grain yield of the subsequent wheat (Triticum aestivum L.) crop was in the order: sesbania (3.79 $\left.\mathrm{Mg} \mathrm{ha} \mathbf{a}^{-1}\right) \approx \operatorname{gypsum}\left(3.68 \mathrm{Mg} \mathrm{ha}^{-1}\right)>$ Kallar grass $\left(3.14 \mathrm{Mg} \mathrm{ha}^{-1}\right)>$ sordan $\left(2.27 \mathrm{Mg} \mathrm{ha}^{-1}\right)>$ control $\left(0.65 \mathrm{Mg} \mathrm{ha}^{-1}\right)$. In a later field experiment [5], four plant species - Kallar grass, sesbania, millet rice, and finger millet - were tested against gypsum application (14.8 $\mathrm{Mg} \mathrm{ha}^{-1}$ ) to ameliorate a calcareous, sandy clay loam, saline-sodic soil $\left(\mathrm{EC}_{\mathrm{e}}=9.1-11.0 \mathrm{dS} \mathrm{m}^{-1}, \mathrm{SAR}=59.4-72.4\right)$. The treatment effectiveness to decrease soil EC.e and SAR was in the order: gypsum $\approx$ sesbania $>$ Kallar grass $>$ millet rice $>$ finger millet. Forage yields of the plant species were directly proportional to their soil amelioration efficiency.

Some field trials of $\mathrm{cmp}$ bioremediation techniques have not been successful primarily because a salt-resistant forage $\mathrm{cmp}$ was not the first crop in the rotation. In a field experiment [12], biological (rice-wheat rotation), physical + biological (subsoiling by curved chisels to a depth of $0.5 \pm 0.05 \mathrm{~m}$ at a chisel spacing of 1.2-1 -5 $\mathrm{m}+$ rotation), chemical + biological (gypsum at $100 \%$ gypsum requirement of the upper 0.15 th of soif + rotation), and chemical + physical + biological (gypsum + subsoiling + rotation) methods were compared to ameliorate two calcareous salinesodic soils. Irrigation water $\left(\mathrm{EC}=1.8 \mathrm{dS} \mathrm{m}^{-1}, \mathrm{SAR}=9.8\right)$ was applied according to the crop water requirement. The first crop in the rotation was rice, which was a complete failure and did not produce any grain on one soil $(\mathrm{pH},=8.6-9.1, \mathrm{EC}$, $\left.=12.3-15.0 \mathrm{dS} \mathrm{m}^{-1}, \mathrm{ESP}=58.7-74.6\right)$, and a grain yield of $0.72 \mathrm{Mg} \mathrm{ha}^{-1}$ on the other soil $\left(\mathrm{pH}_{\mathrm{s}}=8.8-8.9, \mathrm{EC}_{\mathrm{e}}=9.6-15.2 \mathrm{dS} \mathrm{m}^{-1}, \mathrm{ESP}=42.5-45.6\right)$. Four years after cropping. the average rice grain yield from both soils was in the order: gypsum $\left(1.99 \mathrm{Mg} \mathrm{ha}^{-1}\right)>$ gypsum+ subsoiling $\left(1.84 \mathrm{Mg} \mathrm{ha}^{-1}\right)>\operatorname{subsoiling}(1.41$ $\left.\mathrm{Mg} \mathrm{ha}{ }^{-1}\right)>$ vegetative bioremediation $\left(1.02 \mathrm{Mg} \mathrm{ha}^{-1}\right)$. Gypsum and gypsum + subsoiling treatments had similar values for the wheat grain yield $\left(2.72 \mathrm{Mg} \mathrm{ha}^{-1}\right)$ followed by subsoiling (1.79 $\mathrm{Mg} \mathrm{ha}^{-1}$ ) and vegetative bioremediation (1.46 Mg $\mathrm{ha}^{-1}$ ). Within the upper $0.15 \mathrm{~m}$ depth, all the treatments decreased EC, levels less than $5 \mathrm{dS} \mathrm{m}^{-1}$ and ESP levels less than 22 on both the soils.

Several crop rotations have been evaluated for the amelioration of saline-sodic and sodic soils. The imgated crop rotations were tested to ameliorate a calcareous saline-sodic field $\left(\mathrm{pH},=8.1-8.2, \mathbf{E C},=9.2-13.7 \mathrm{dS} \mathrm{m}^{-1}, \mathrm{SAR}=30.6-42.7\right)$. The rotations distributed in plots of $18 \mathrm{~m}^{2}$ were: sesbania-barley (Hordeurn vulgare L.), rice-wheat, and Kallar grass-alfalfa (Medicago sativa L.). All the crop rotations reclaimed the upper $0.15 \mathrm{~m}$ of soil after 1 year $(\mathrm{SAR}<10)$ as did amelioration by thenon-cropped gypsum treatment, which decreased SAR less than 14[13].Although initial salinity and sodicity levels of this soil were closer to that used by [12], there were three differences: I) the soil was relatively coarser in texture, 2) the plots were imgated with canal water $\left(\mathbf{E C}=0.3 \mathrm{dS} \mathrm{m}^{-1}, \mathrm{SAR}=0.5\right)$. and 3$)$ the irrigation water was applied in excess of crop water needs to leach $\mathrm{Na}^{+}$to lower depths.

In an evaluation of 14 experiments, carried out in different parts of the world. there was a comparable effect of chemical and bioremediation approaches [14].The chemical treatment (application of gypsum in all experiments) caused $62 \%$ decrease 
in original sodicity levels, whereas a $52 \%$ decrease was calculated for the vegetative bioremediation treatments. However, in some experiments bioremediation was either unsuccessful or much less efficient than the chemical treatmentfor the reasons: 1) a crop resistantto ambient soil salinity and sodicity levels was not the first in the crop rotation; 2) bioremediation crop was grown during the time, which was not its most suitable growing season; 3) time was insufficient to exploit the potential impact of the bioremediation crop; and/or 4) irrigation was not applied in excess of crop water requirement, which restricted the downward movement of $\mathrm{Na}^{+}$from the root zone. In general. bioremediation worked well on moderately sodic and saline-sodic soils, provided 1) irrigation was in excess of crop water requirement to provide adequate leaching; and 2) the excess imgation was applied when the crop growth and hence $\mathrm{PCO}_{2}$ were at their peak. On these soils, the performance of vegetative bioremediation was comparable with soil application of gypsum. On highly sodic and saline-sodic soils, chemical treatment was better than the cropped treatments.

\section{Additional benefits of vegetative bioremediation}

Nutrient availability status of post-amelioration soil is crucial for the growth of subsequent crops. Research on nutrient behavior during amelioration using chemical and biological methods has been conducted by determining the availability status of some macro- and micro-nutrients during amelioration of a calcareous saline-sodic soil $\left(\mathrm{pH},=8.2-8.6, \mathrm{EC}_{\mathrm{e}}=7.4-9.0 \mathrm{dS} \mathrm{m}^{-1}, \mathbf{S A R}=55.6-73.0\right)$. The bioremediation treatments included cropping of sesbania, sordan, or Kallar grass for 15 months. There was an increase in phosphorus $(\mathrm{P})$, zinc $(\mathrm{Zn})$, and copper $(\mathrm{Cu})$ availability $\mathrm{i} n$ the bioremediation plots resulting from the production of root exudates and likely dissolution of some nutrient-coated calcite. Conversely, the non-cropped gypsum treatment decreased the availability status of these nutrients. Besides leaching losses, adsorption of nutrients on some newly formed $\mathrm{CaCO}_{3}$, a secondary consequence of gypsum'dissolution, contributed to this decrease. Soil $\mathrm{N}$ content was decreased in all the treatments except for $\mathrm{N}_{\mathbf{2}}$-fixing sesbania treatment where $\mathrm{N}$ content was increased from $0.49 \mathrm{~g} \mathrm{~kg}^{-1}$ to $0.53 \mathrm{~g} \mathrm{kg-'.} \mathrm{There} \mathrm{was} \mathrm{no} \mathrm{treatment} \mathrm{effect} \mathrm{on} \mathrm{soil} \mathrm{potassium(K)}$ availability since illite, a K-bearing mineral, was dominant in the clay fraction [15].

Soil microbial biomass is an agent of transformation for added and native organic matter and acts as a labile reservoir for several plant-availablenutrients. The activity of microbial biomass is commonly used to characterize microbiological status of a soil and to determine the effects of agricultural practices on soil microorganisms. Dehydrogenase activity (DHA) in soils is related to microbial populations, respiration activity and soil organic matter, and provides an index of the overall microbial activity [16]. This parameter has been studied in few experiments dealing with sodic soil amelioration through chemical and biological means. After using several combinations of chemical and vegetative bioremediation treatments, DHA and microbial biomass carbon (MBC) were determined [17]. The treatments consisted of Kamal grass grown for 1 or 2 years (harvested biomass removed or left to decompose on the soil surface), gypsum application (at $14 \mathrm{Mg} \mathrm{ha}^{-1}$ ) + Kamal grass, gypsum + sorghum, gypsum + rice, and gypsum + sesbania. The soil on which these treatments were applied was alkali $\left(\mathrm{pH}_{1: 2}=10.6, \mathrm{EC}_{1: 2}=2.1 \mathrm{dS} \mathrm{m}^{-1}\right.$, ESP $=95$, DHA 
$=4.5 \mu \mathrm{g}$ triphenylformazan $\left.\mathrm{g}^{-1}, \mathrm{MBC}=56.7 \mathrm{mg} \mathrm{kg}-{ }^{\prime}\right)$. The levels of DHA in post-amelioration soil were greater $\left(118.7 \mu \mathrm{g}\right.$ triphenylfomazang $\left.{ }^{-1}\right)$ in the bioremediation treatments than gypsum + crop treatments $(96.1 \mu \mathrm{g}$ triphenylformazan $\left.\mathrm{g}^{-1}\right)$. The MBC values were greater in gypsum + crop treatments $(206.3 \mathrm{mg} \mathrm{kg-'}$ soil) than in the cropped treatments ( $161.7 \mathrm{mg} \mathrm{kg}^{-1}$ soil). The overall experimental averageof MBC (184 mg kg-' soil) for all the treatments was more than three times the initial level of $56.7 \mathrm{mg} \mathrm{kg}^{-1}$ soil. In an earlier study [18], a significant increase in urease and dehydrogenase activities was found in alkali soils under permanent vegeration such as grasses. Green manuring of an alkali soil with sesbania has also been reported to increase urease and dehydrogenaseactivities [19].

Sodic and saline-sodic soils have lost a large fraction of their original carbon (C) pool [20]. The magnitude of the loss may range between 10-30 $\mathrm{Mg} \mathrm{C} \mathrm{hal}^{-1}$, depending on the antecedent pool and the severity of degradation. The soil $\mathrm{C}$ pool is not only important for the soil to perform its productivity and environmental functions, but also plays an important role in the global $\mathrm{C}$ cycle. In addition to amelioration effect, cultivation of appropriate crops, shrubs, and trees on sodic and saline-sodic soils has the potential to mitigate accelerated greenhouse effects by increasing soil $\mathrm{C}$ through biomass production (Tab. 1). Monitoring changes in an alkali soil cropped with four tre species - acacia (Acacia nilotica Willd ex Delile), shisham (Dalbergia sissoo Roxb. ex DC.), mesquite (Prosopis juliflora (Swartz) DC.) and arjuna (Terminalia arjuna Bedd.) - suggested shisham and mesquite as more efficient in terms of biomass production and decreasing $\mathrm{Na}+$ levels in the soil. Similarly, there greater microbial activity in upper $0.6 \mathrm{~m}$ soil under these species due to the accumulation of humus from decomposition of leaf litter and root decay, which increased soil organic C:The rate of increase was low for thefinst 2-4 years, exponential between 4-6 years, and plateau at a low rate for 6-8 years [21]. Establishment of mesquite on a sodic field increased organic $\mathrm{C}$ of the top $1.2 \mathrm{~m}$ soil from $118 \mathrm{MgC} \mathrm{ha}^{-1}$ to $13.3 \mathrm{MgC} \mathrm{ha}^{-1}$ in 5 years, $34.2 \mathrm{MgC} \mathrm{ha}^{-1}$ in 7 years, and $54.3 \mathrm{Mg} \mathrm{C} \mathrm{ha}^{-1}$ in 30 years. The average annual rate of increase in soil organic C was $1.4 \mathrm{Mg} \mathrm{ha}^{-1}$ over the 30 -year period [22]. Other estimates from field studies on alkali soils suggest that different land-use systems consisting of a number of grasses and trees can sequesterorganic $\mathrm{C}$ in the range of $0.2-0.8 \mathrm{Mg} \mathrm{Cha}^{-1} \mathrm{yr}^{-1}$ [6].

\section{Plant species for vegetative bioremediation}

The selection of plant species for vegetative bioremediationis generally based on the ability of the species to withstand ambient levels of soil salinity and sodicity while also providing a saleable product or one that can be used on-farm. Considerable variation exists among crops to withstand saline-sodic conditions [23]. Such interand intra-crop diversity suggests that field trials be conducted to identify local crops that are adaptable to saline-sodic soil conditions [24]. The fanners, farm advisors, and researchers familiar with local conditions, including crop response to adverse soil conditions and cropping strategies that fit into the local economic conditions, could provide a valuable resource base for making appropriate recommendations. In addition, application of plant breeding approaches is needed to develop crop genotypes with enhanced salt resistance and performance in field conditions [25]. 
Table 1. Potential of two land-use systems (grass only and tree-grass) for carbon (C) sequestration in a calcareous alkali soil $\left(\mathrm{pH}=10.0-10.2 ; \mathrm{EC}=\mathbf{2 . 0 - 6 . 4 d S ~ \mathrm { m } ^ { - 1 } )}\right.$. Recalculated from [6]

\begin{tabular}{|c|c|c|c|c|}
\hline \multirow[t]{2}{*}{ Treatment $^{\text {nh }}$} & \multicolumn{3}{|c|}{ Organic $\mathbf{C}$ in soil $\left(\mathrm{g} \mathrm{kg}^{-1}\right)$ at different depths ${ }^{\mathrm{b}}$} & \multirow{2}{*}{$\begin{array}{l}\text { C sequestration } \\
\left(\mathrm{Mg} \mathrm{ha}^{-1} \mathrm{yr}^{-1}\right)^{\circ}\end{array}$} \\
\hline & $0-0.075 \mathrm{~m}$ & $0.075-0.15 \mathrm{~m}$ & Mean & \\
\hline Desmostachya & 2.9 & 1.6 & 2.3 & 0.33 \\
\hline Spombolus & 2.4 & 1.3 & 1.8 & 0.17 \\
\hline Acacia + Desmostachya & 3.6 & 1.8 & 2.7 & 0.47 \\
\hline Dalbergia + Desmostachya & 4.6 & 2.4 & 3.5 & 0.73 \\
\hline Prosopis + Desmostachya & 4.7 & 2.5 & 3.6 & 0.77 \\
\hline Acacia + Desmostachya & 2.6 & 1.4 & 2.0 & 0.23 \\
\hline Dalbergia + Desmostachya & 3.2 & 1.7 & 2.5 & 0.40 \\
\hline Pmsopis + Desmostachya & 3.6 & 1.9 & 2.8 & 0.50 \\
\hline
\end{tabular}

'Desmostachya (Desmostachya bipinnata (L.) Stapf), Spombolus (Spombolus marginatus Hochst ex A. Rich), Acacia (Acacia nilotica (L) Delile), Dalbergia (Dalbergia sissoo Roxb. ex DC) ,Pmsopis (Pmsopisjuliflora (Sw.) DC)

${ }^{b}$ After 6 years of plantation

'Assuming initial C content in the soil as $1.3 \mathrm{~g} \mathrm{~kg}^{-1}$ (average of the $\mathrm{C}$ content, which ranged from 1.0-1.6 $\mathrm{g} \mathrm{kg-'}$ ) and mass of $0.15 \mathrm{~m}$ depth of 1 ha as $2 \times 10^{6} \mathrm{~kg}$, the rate of organic C sequestration in the soil under each treatment was calculated as:

Organic C sequertr $\left(\mathrm{Mg} \mathrm{ha}^{-1} \mathrm{yr}^{-1}\right)=[($ mean $\mathrm{C}$ content -original $\mathrm{C}$ content in soil $) 2]$ / 6

Several crops, shrubs, trees, and grasses have been used as vegetativebioremediation tools to ameliorate sodic and saline-sodic soils. Some researchers have favored the inclusion of Kallar grass [9], sesbania [11], alfalfa [26], Bermuda grass [8], or sordan [4] as the first $\mathrm{cmp}$ to accelerate sodic soil amelioration. Several other plant species have produced adequate biomass on salt-affected soils. These include shrub species from the genera Atriplex and Maireana [27, 28], Kochia scoparia L. [29], Salicornia bigelovii Torr. [30], Echinochloa crusgalli (ㄴ.) P. Beauv. [31], and Portulaca oleracea L. [32], among others. However, it is imperative to compare them with other species already tested for sodic soil amelioration. In addition, efforts are needed to search other cropssuch as high-value medicinal and aromatic species with the potential for adequate growth on sodic and saline-sodic soils.

A number of tre plantations have been grown on sodic and saline-sodic soils. These include: Terminalia arjuna (Roxb. ex DC.) Wight and Am. [33], Pmsopis juliflora(Sw.)DC. [22],Dalbergin sissoo Roxbex DC.,Acacia nilotica (L.)Willd. ex Delile [6], Parkinsoninaculeata L. and Prosopis cineraria (L.) Druce [34],Sesbania sesban (L.) Merr. and Tamarixdioica Roxb. ex Roth [35], and Leucaena leucocephala (Lam.) de Wit [36], among others. In Australia, revegetation by trees was found to be the best long-term option for controlling dryland salinity [37]. Useful information is available regardingsources of seeds, nursery raising techniques, and land preparation 
and planting procedures for 18 different tree and shrub species with potential for growth on salt-affected soils [34].

Based on cost and benefit analysis, several studies have compared economics of sodic soil amelioration. A net economic loss (cost:benefit 1.00:0.75) was found during vegetative bioremediationalthough the growth of Kamal grass was adequate, which helped reduce soil sodicity. The economic Loss was attributed to the small market demand of the grass in the presence of other good-quality forages in that locality [38]. On the other hand, the bioremediation strategy has been found to be economically beneficial when there was a market demand or local utilization of the crops at the farm level $[39,40]$. Agroforestty systems comprising several tree species on saline-sodic soils have been found to be economically feasible in some developing countries because of firewood need in local markets [36]. On the other hand, the market for firewood is not supportive to make agroforestry economically viable in California [8]. Preliminary assessments in Australia suggest that there are 26 salt-resistant plant species capable of producing 13 products (or services) of value to agriculture [27]. From an economic perspective much depends on local needs. In an immediate sense, vegetative bioremediationcan only be economically feasible if the selected crops, grasses, or trees have a market demand or local utilization at the firnlevel. In the long run, one must also consider the value of the improved soils.

\section{Conclusions}

In recent decades,vegetative bioremediation bas been found to be an efficient,inexpensive, andenvironmentally acceptable strategy to amelioratesodic and saline-sodic soils. Its comparable performance with that of chemical amelioration highlights the effectiveroleof croppingin the amelioration of these soils. Vegetative bioremediation has shown to be advantageous in several aspects: 1)no financialoutlay to'purchase chemical amendments, 2) accrued financial or other benefits from crops grown during amelioration, 3) promotion of soil-aggregate stability and creation of macro-pores that improve soil hydraulic properties and root proliferation,4) greater plant-nutrient availability in soil after vegetativehioremediation,5) more uniform and greater zone of amelioration in terms of soil depth, 6) sequestration of $\mathrm{C}$ in post-amelioration soil, and 7) environmentally feasible and productive use of otherwise marginal and degraded soils. However, vegetative bioremediation is slower in effecting positive change than chemical approaches and is contingent on the presence of calcite in soil, which is common when compared to most sodic and saline-scdic soils of arid regions. In addition, its scope becomes limited on highly sodic soils where growth of the bioremediationcrops is likely to be variable and patchy and the use of chemical amendments such as gypsum is inevitable. Clearly, vegetative bioremediation is an effectivelow-cost intervention for resource-poorfanners. This approach has the potential for large-scale adoption under government or community-based programs aimed at the amelioration and improved productivity of degraded common property resources. 


\section{References}

1 Ghassemi F, Jakeman AJ, Nix HA (1995) Solinisation of Landand Water Resources. Human Causes, Extent, Managementand Case Studies. CABI Publishing, Wallingfor」, UK

2 Gupta RK, Abrol IP(1990)Salt-affectedsoils: their reclamation and managementfor crop production. Adv Soil Sci 11:223-288

3 Qadir M, Oster JD (2002) Vegetative bioremediation of calcareous sodic soils: history, mechanisms, and evaluation. Irrigation Sci 21: 91-101

4 Robbins CW (1986) Sodic calcareous soil reclamation as affectud by different amendmenis and crops. Agron J 78: 916-920

5 Qadir M, Qureshi RH, Ahmad N, Ilyas M (1996) Salt-tolerant forage cultivation of a saline-sodic field for biomass production and soil reclamation. Land Degrad Develop 7 : $11-18$

6 Kaur B, Gupta SR, Singh G(2002)Bioamelioration of a sodic soil by silvopastoral systems in northwestern India. Agroforestry Systems 54: 13-20

7 McGrath SP, Zhao FJ, Lombi E (2002) Phytoremediation of metals, metalloids. and radionuclides. Adv Agmn 75: 1-56

8 Oster ID, Shainberg I, Abrol IP (1999) Reclamationof salt affected soils. In: RW Skaggs, I van Schilfgaarde (eds) In: Agricultural Drainage. ASA-CSSA-SSSA, Madison, USA, 659-691

9 Kumar A, Abrol IP (1984) Studies on the reclaiming effect of Karnal-grass and para-grass grown in a highly sodic soil. Indian J Agric Sci 54: 189-193

10 Hamid A, Chaudhry MR, Ahmad B (1990) Biotic reclamation of a saline-scdic soil. In: Proceedings of Symposium on Irrigation S: s is Management/Research, 73-86. 12 t November 1990. USAID and Government of Pakistan. Islamabad. kistan

11 Ahmad N, Qureshi RH, Qadir M (1990) Amelioration of a calcareous saline-scdic soil by gypsum and forage plants. Land Degrad Rehabil 2: 277-284

12 Muhammed S, Ghafoor A, Hussain T, Rauf A (1990) Comparison of biological, physical and chemical methods of reclaiming salt-affected soils with brackish groundwater. In: Proceedings of the 2nd National Congress of Soil Science, 35-42, 20-22 December 1988, Soil Science Society of Pakistan, Faisalabad, Pakistan

13 Qadir M, Ahmad N, Qureshi RH, Qasim SM, Javaid M (1992) Biochemical reclamation of a calcareous saline-sodic soil. Pakistan J Agric Sci 29: 406-411

14 Qadir M, Oster JD (2004) Crop and irrigation managementstrategiesfor saline-sodicsoils and waters aimed at environmentally sustainable agriculture. Sci Total Envimn 323: 1-19

15 Qadir M, Qureshi RH, Ahmad N (1997) Nutrient availability in a calcareous saline-sodic soil during vegetative bioremediation.Arid Soil Res Rehabil 11:343-352

16 Włodarczyk T, Stępniewski W, Brzezińska M (2002) Dehydrogenase activity, redox potential, and emissions of carbon dioxide and nitrous oxide from Cambisols under flooding conditions. Biology Fertility Soils 36: 200-206

17 Batra L, Kumar A, Manna MC, Chhabra R (1997) Microbiologicaland chemical amelioration of alkaline soil by growing Kamal grass and gypsum application. Exp Agric 33: 389-397

18 Rao DLN, Ghai SK (1985) Urease and dehydrogenase activity of alkali and reclaimed soils. Australian I Soil Res 2: 661-665

19 Rao DLN, Pathak H(1996) Ameliorativeinfluenceof organic maner on biologicalactivity of salt-affected soils. Arid Soil Res Rehabil 10: 311-319

20 Lal R (2001) Potential of desertification control to sequester carbon and mitigate the greenhouse effect. Climatic Change 51: 35-72 
21 Garg VK (1998) Interaction of tree crops with a sodic soil environment: potential for rehabilitation of degraded environments. Land Degrad Develop 9: 81-93

22 Bhojvaid PP, Timmer V (1998) Soil dynamics in an age sequence of Pros'pis juliftora planted for sodic soil restoration in India. Forest Ecol Manage 106: 181-193

23 Maas EV, Grattan SR (1999) Crop yields as affected by salinity. In: RW Skaggs, J van Schilfgaarde (eds) In: Agricultural Drainage. ASA-CSSA-SSSA, Madison, USA 55-108

24 Shannon MC (1997) Adaptation of plants to salinity. Adv Agron 60: 76-120

25 Pinan MG, Laüchli A (2002) Glohal impact of salinity and agricultural ecosystems. I : 4 Laiichli, U Lüttge (eds) Salinity: Environment-Plants-Molecules. Kluwet, Dordrecht, The Netherlands, 3-20

26 Ilyas M, Miller RW, Qureshi RH (1993) Hydraulic conductivity of saline-sodic soil after gypsum application and cropping. Soil Sci Soc Am J 57: 1580-1585

27 Barrett-Lennard EG (2002) Restoration of saline land through revegetation. Agric Wafer Manage 53: 213-226

28 Malcolm CV (1993) The potential of halophytes for rehabilitation of degraded lands. In: N Davidson, R Galloway (eds) In: Productive Use of Saline Land. ACIAR Proceedings 42. Perth, Western Australia, 8-1 1

29 Garduno MA (1993) Kochia: A new alternative for forage under high salinity conditions of Mexico. In: H Lieth, A Al Masoom (eds) In: Towards the Rational Use of High Salinify Tolerant Plants (Volume 1). Kluwer Academic Publishers, The Netherlands, 459-464

30 Glenn E, Hicks N, Riley J, Swingle S (1996) Seawater irrigation of halophytes for animal feed. In: R Choukr-Allah \& al, (eds) In: Halophytes and Biosaline Agriculture. Marcel] Dekker, Inc., New York, USA. 221-236

31 Aslam Z, Saleem M. Qureshi RH, Sandhu GR (1987) Salt tolerance of Echinochloa crusgalli. Biologia Plantarum 29: 66-69

32 Grieve CM, Suarez DL (1997) Purslane (Portulaca oleracea L.): A halophytic crop for drainage water reuse systems. Plant Soil 192: 277-283

33 Jain RK, Singh B (1998) Biomass production and soil amelioration in a high density Teminalia Arjuna plantation on sodic soils. Biomass Bioenergy 15: 187-192

34 Qureshi RH. Bartet-Lennard EG (1998) Saline Agriculturefor Irrigated Land in Pakistan: A Handbook. Australian Centre for International Agricultural Research, Canberra, Australia

35 Singh B (1989) Rehabilitation of alkaline wasteland on the Gangetic alluvial plains of Uttar Pradesh, India, through afforestation. Lard Degrad Rehabil 1: 305-310

36 Qureshi RH, Nawaz S, Mahmood T (1993) Performance of selected tree species under saline-sodic field conditions in Pakistan. In: HLieth, A Al Masoom (eds) In: Towards the Rational Use of High Salinity Tolerant Plants (Volume 1). Kluwer Academic Publishers, The Netherlands, 259-269

37 Farrington $P_{4}$ Salama RB (1996) Controlling dryland salinity by planting trees in the best hydrogeological setting. Land Degrad Develop 7: 183-204

38 Singh MV, Singh KN (1989) Reclamation techniques for improvement of sodic soils and crop yields. Indian $J$ Agric Sci 59: 495-500

39 Chaudhry MR, Abaidullah M (1988) Economics and effectiveness of biological and chemical methods in soil reclamation. Pakistan J Agric Res 9: 106-114

40 Sandhu GR, Qureshi RH(1986) Sait-affected soils of Pakistan and theirutilization. Reclam Reveg Res 5: 105-113 